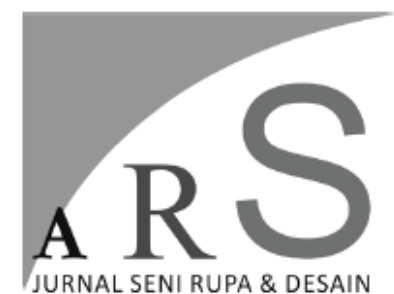

Volume 22 Nomor 2,

Agustus 2019

\section{DESAIN MOTIF UKIR UNTUK PUBLIKASI WISATA PANTAI}

\author{
Eko Darmawanto*, Muchammad Qomaruddin* \\ *StafPengajar Universitas Islam Nahdlatul Ulama Jepara \\ E-mail: ekodarmawanto@unisnu.ac.id, qomar@unisnu.ac.id
}

\begin{abstract}
ABSTRAK
Hingga saat ini motif ukir masih menjadi karakter yang kuat dalam mitologi di wilayah Jepara yang perlu dikokohkan dengan bentuk yang berbeda dan terintegrasi dengan dunia wisata sebagai pintu gerbang dalam memperkenalkan ikonik ukir kepada dunia luar. Kegiatan publikasi dengan unsur seni dan budaya saat ini belum menyentuh ranah unsur motif, sehingga desain yang bersifat ketimuran saat ini telah pudar dari yang seharusnya. Upaya penelusuran data berdasarkan realitas lapangan pada penelitian awal menunjukkan setidaknya terdapat sebaran wisata pantai Jepara yang memiliki potensi kuat dalam pengembangan desain publikasi dengan balutan motif. Dengan data yang komprehensif setidaknya diperoleh manfaat dalam penelitian ini yaitu: (1) perancangan desain melalui motif ukir sebagai penunjang publikasi wisata pantai dalam bentuk desain ikonik; (2) hasil penelitian ini dapat dijadikan masukan kebijakan untuk perubahan perbub no. 10 tahun 2014 di wilayah kabupaten Jepara terkait cakupan bangunan ikonik yang tidak hanya di lingkungan pemerintah semata melainkan juga objek wisata. Metode penelitian dengan menggunakan metode glass box, yakni desain yang terukur, sistematis, dan rasional dengan pendekatan budaya lokal dan analisis data menggunakan alur Specific, Measurable, Attainable, Relevant, Timely (SMART).
\end{abstract}

Kata kunci: desain, motif klasik

\begin{abstract}
Until today, mythology still holds a crucial role in establishing the character of Jepara carving. To introduce this iconic craft to the world, there is a need for a synergy between the craft industry and tourism sector. Publication on art and culture so far has not displayed the elements of motif in details so that there is a tendency to ignore these Eastern designs. Data gathering at the early stage of the research shows that there are some promising potentials in tourism places located in Jepara shores that can be promoted using publication design incorporating carving motifs. The benefits of this study are: 1) it result in an iconic design to support tourism publication; 2) the result of this study can contribute to the revision of the coverage the Regent Regulation number 10 Year 2014 saying that the iconic forms should be used in government buildings can be widened to include tourism places too. Method used in this research is the glass box where design is should be measureable, systematic, and rational supported by local cultue approach. The collected data were analyzed using SMART guidance stands for Specific, Attainable, Relevant, and Timely.
\end{abstract}

Keywords: design, classicmotifs 


\section{Pendahuluan \\ Latar Belakang}

Motif ukir merupakan produk budaya yang berasaskan pada norma suatu masyarakat tertentu, seperti di Jawa atau wilayah Jepara. Motif ukir selalu terhubung erat dengan sejarah terbentuknya sebuah peradaban maju, di mana peradaban manusia memiliki tingkat kepercayaan akan nilai-nilai luhur yang terekam dalam aturan yang dinamai sebagai norma. Tidak mengherankan jika salah satu tema wisata Jepara memasukkan unsur motif dan ukir sebagai jargon maupun tujuan wisata. Motif ukir memiliki setidaknya fungsi, yakni aktif dan pasif. Fungsi aktif terkait dengan manfaat teknisnya sebagai tatanan ataupun strata sosial dalam masyarakat, sedangkan fungsi pasif terkait nilai estetis yang terimplementasikan di dalamnya sebagai sarana hias. Adanya perkembangan ikonik ukir Jepara dari masa yang kian maju, menunjukkan bahwa nilai aktif lebih ditonjolkan jika dibandingkan dengan nilai pasifnya. Hal ini menimbulkan pesan praktis konsumtif, sehingga berimbas pada pola motif hias yang kabur dan berkembang liar, sehingga keluar dari pakem atau tatanan dalam menciptakan motif ukir.

Dari kriteria fisik, motif ukir berkembang dengan berbagai material pada awalnya, namun saat ini yang masih dapat dilihat dalam bentuk artefak hanya berbahan

tanah liat, kayu, logam, dan material batuan alam. Motif ukir terbilang unik meskipun tidak terpapar dengan jelas dari sisi filosofisnya, disebabkan pola penciptaan yang rekam jejaknya kurang diteliti, sehingga nyaris tidak pernah terpublikasi. Setidaknya pada aspek komposisi gubahan bentuk visual alam seperti daun dan unsur raut menjadi hal yang cukup menarik untuk dapat dijadikan motif ukir, sebagai material uji dalam pengembangan ikonik desain wisata pantai sebuah wilayah. Terkait dengan hal tersebut, maka tidaklah cukup sebuah motif hanya dipakai dalam bentuk konsumtif sebagai sebuah bentuk produk semata, akan tetapi nilai edukasi dan implementasi publikasi monumental juga dibutuhkan sebagai bagian untuk mempertegas karakter ikonik wilayah terutama tempat wisata pantai Jepara sebagai pintu masuk wisatawan lokal maupun manca.

Wisata pantai Jepara merupakan tempat yang cocok dari sisi historis mulai dari cerita foklor tentang R.A. Kartini sampai budaya pengrajin ukir yang dapat diintegrasikan di wilayah wisata, yang masih sedikit yang terekspos ke dalam bentuk buku maupun artikel ilmiah. Tidak berhenti sampai di situ saja, bahkan aktualisasi bangunan memiliki potensi dikembangkan sebagai kawasan ikonik yang memiliki potensi luar biasa yang bisa digali dan dikonservasikan untuk dikembangkan dalam bentuk metode/cara/teknik perancangan publikasi baru yang pada akhirnya mampu dikembangkan ke dalam dunia desain melalui bentuk publikasi lewat motif ukir dan produk turunannya. Fakta menunjukkan, bahwa motif ukir tercipta berlandaskan perilaku yang berlaku dalam tatanan masyarakat khususnya Jepara, dan daerah pantai di mana terdapat kepercayaan, mitos, dan cerita foklor yang harus diimplementasikan dengan situasi agung atau asas keagungan yang mampu terlihat. Hal tersebut yang akhirnya dapat dilegalkan ke dalam bentuk visual tradisi, salah satunya dalam bentuk stilasi atau gubahan bentuk sebenarnya atau mendekati kebenaran untuk dapat dinikmati, dikagumi, dan pada akhirnya dipuja sebagaimana fungsi aktif motif yang diinginkan.

Situasi yang berkembang saat ini menjadikan ikonik motif ukir tidak dapat disangkal lagi, mengingat Jepara memiliki banyak sekali daerah potensial pariwisata pantai. Untuk dapat menciptakan iklim publikasi tanpa stagnasi, diperlukan sebuah upaya agresif dalam menemukan terobosan baru dalam bidang lain untuk dapat merawat tradisi sekaligus memberikan efek informatif dan normatif kepada publik. Hal yang menarik sehingga diperlukan adanya proses teknis yang harus ditemukan, sehingga tidak terjadi proses 
mati suri. Dibutuhkan sebuah terobosan yang baru dalam hal perancangan desain monumental di lokasi wisata pantai dalam bentuk desain dengan material publikasi yang berbeda, sehingga tidak menghilangkan motif ukir yang memang sudah ada sejak dulu terikat secara kuat dalam masyarakat lokal. Untuk dapat membuat penguatan ikonik pada motif ukir terutama daerah Jepara, maka diperlukan penelitian lebih lanjut yang lebih menitik beratkan kepada pengembangan karakter motif dengan subtansi publikasi yang mampu menjadi sebuah pesan dan daya tarik wisata pantai dengan balutan tradisi budaya lokal yang lebih fleksibel, sehingga warisan leluhur tetap dipertahankan keberadaannya.

Tahun 2006 berdasarkan laporan

LSM Celcius yang terbit hari sabtu 20 September 2008, didapatkan permasalahan yang terkait dengan budaya foklor Jepara terutama model desain ukir kayu yang dipermasalahkan oleh seorang warga negara asing, terkait hak cipta yang setelah dilakukan audiensi dan pengkajian ulang, hal tersebut tidaklah benar dan cenderung menyalahgunakan hak cipta yang berlebihan untuk kepentingan pribadi. Permasalahan ini pada akhirnya membuat pemerintah kabupaten Jepara menggalakkan program pengayaan motif tradisi yang mampu mendorong kreatifitas masyarakat Jepara, terkait dengan budaya motif dan berbagai implementasi material di mana salah satunya melalui peraturan Bupati Jepara no 10 tahun 2014 tentang pemberian ornamen ukiran pada gedung dan bangunan lain milik pemerintah daerah Jepara (Jdih.jeparakab.go.id, 2014). Namun demikian, perbub tersebut pada kenyataanya tidak dibarengi dengan semangat kelembagaan di bawahnya, sehingga perbub ini tidak dapat diejawantahkan atau di implementasikan. Dunia publikasi wisata yang seharusnya menjadi ikonik kota Jepara juga luput dari peraturan bupati tersebut. Pariwisata memiliki peran krusial sebagai pintu masuk orang luar untuk dapat mengenal Jepara lebih dekat, sehingga pintu masuk wisatawan inilah yang harus menjadi perhatian, sudah seharusnya tempat wisata pantai dapat dijadikan penguatan karakter, sehingga contoh kasus foklor tentang ukir di daerah Jepara dapat dijadikan momentum awal, bahwa konsep desain melalui motif dapat menjadi bagian dalam penguatan nilai kearifan lokal sebagai budaya kerakyatan bukan milik perorangan, sehingga perlunya dikembangkan pola desain pengayaan desain melalui motif ukir dengan dasar-dasar perilaku budaya masyarakat lokal yang mengalami mati suri sudah sejak lama terutama di daerah Jawa. Berdasarkan atas fenomena permasalahan di atas, maka diperlukan adanya kajian ulang mengenai pengembangan desain publikasi yang unik dan berbeda di lokasi wisata pantai Jepara. Harapannya mampu diimplementasikan dalam mendukung penguatan ikonik Jepara dan tetap mengusung tradisi sebagai bagian dari produk budaya masyarakat Jepara, sehingga mampu terintegrasi dan memberikan dampak praktis bagi Jepara. Peneliti merumuskan masalah mengenai pengembangan desain melalui motif ukir sebagai penunjang publikasi wisata pantai dalam bentuk desain landscaping.

\section{Tujuan Penelitian}

Adapun tujuan penelitian adalah untuk mengembangkan perancangan desain melalui motif ukir sebagai penunjang publikasi wisata pantai dalam bentuk desain landscaping.

\section{Teori}

\section{Pengembangan Desain}

Konsep pengembangan sudah sejak lama dikemukakan, baik dalam lingkup keilmuan seperti sosial maupun keilmuan dengan unnsur budaya dan ilmu lainnya. Istilah pengembangan merupakan konteks umum yang mampu dikaitkan dengan disiplin ilmu yang berbeda rumpun. Pada dasarnya konteks pengembangan menurut Kamus Besar Bahasa Indonesia(Departemen Pendidikan Nasional, 2008) berasal dari kata benda yang dimaknai sebagai proses atau cara untuk maju atau berubah, sehingga konteks pengembangan 
sangat tergantung dari teks kata kerja yang dikaitkan dalam hal ini adalah pengembangan desain. sDengan demikian pengembangan desain adalah sebuah proses atau cara melakukan proses teknis dalam membuat desain. Memola, mencipta, mengkonversi, dan selanjutnya mengimplementasikan hasil kerja dengan menggunakan piranti dalam perspektif memperbaiki kinerja. Dalam teori yang menyeluruh, pengembangan desain adalah sebuah cara ataupun proses yang dilakukan secara terstruktur dan ilmiah dengan memikirkan konsep, pola, serta kalkulasi, beserta cara kerja dalam mengembangkan penciptaan karya publikasi dalam output karya yang berasimilasi dalam bentuk.

\section{Motif Ukir dan Pariwisata}

Ukir merupakan teknik yang dilakukan dengan cara memola dan mengurangi sebuah material dengan teknik pahat atau membuat bentuk 3 dimensi (modelling), sedangkan dalam konteks teori motif ukir dimaknai sebagai hiasan yang dibuat dengan cara memola bentuk di atas material tertentu kemudian dilakukan proses mengurangi sebuah material dengan peralatan pahat atau memahat. Untuk dapat memahami konteks motif ukir tidaklah cukup hanya dengan membuat sebuah pola di atas kertas maupun media lain. Apabila belum dilakukan proses memahat atau modelling maka tidak bisa dikatakan sebagai sebuah motif ukir. Konsep teori pengembangan desain melalui motif ukir tradisi untuk publikasi wisata merupakan kegiatan ilmiah yang dilakukan dalam mencipta sebuah publikasi baru dengan material dan proses pengerjaan yang terstruktur dari teknik pengerjaan, dengan melihat faktor normatif budaya yang ada dalam masyarakat guna kepentingan pariwisata.

\section{Metode Penelitian}

Observasi lapangan dan studi literatur merupakan proses pengambilan data primer maupun sekunder yang dibutuhkan sebagai basis data penelitian dalam rangka memberikan input dan referensi teori maupun temuan data di lapangan yang dapat dijadikan dasar dalam pengambilan sampel yang terkait dengan pokok penelitian. Adapun pokok penelitian ini terkait dengan kajian motif ukir dikaitkan dengan publikasi wisata Jepara dalam lingkup pengembangan desainnya.

\section{Identifikasi Masalah}

Pengambilan data dan referensi yang terkumpul dapat dilakukan proses identifikasi permasalahan terkait pokok penelitian, sehingga dapat dilakukan penelitian yang menyeluruh dan terarah. Perlakukan pengidentifikasian masalah merujuk pada rancang bagun dari material penelitian, yakni motif ukir untuk dapat dijadikan media publikasi dalam kawasan pariwisata pantai Jepara yang terdapat di rumusan masalah penelitian dan diselesaikan dalam penelitian.

\section{Pengembangan desain}

Pengembangan desain menggunakan metode glass box yakni perancangan desain yang terukur, sistematis, dan rasional, serta melalui alur proses dekonstruksi meliputi: (1) media implementasi desain; (2) rancang bangun desain publikasi pariwisata; dan (3) peralatan yang dimanfaatkan selama proses penciptaan desain publikasi pariwisata. Setelah ketiga proses dekonstruksi tersebut dicapai maka langkah selanjutnya adalah pengembangan desain yang direkonstruksi berdasar pada identifikasi masalah.

\section{Validasi Desain}

Pemenuhan unsur desainyang telah dicapai dapat dilakukan proses validasi desain di mana keterukuran dan kelayakan desain dapat diperoleh menjadi standar mutu yang baku dan berdurasi masa berlaku desain yang terukur, sehingga dapat diimplementasikan secara nyata. Apabila validasi desain tidak memenuhi unsur uji desain maka dapat 
dilakukan proses perbaikan dan kembali pada proses pengembangan desain.

\section{Analisa}

Pengembangan desain mengalami banyak permasalahan dalam proses implementasinya, sehingga diperlukan sebuah analisa lanjutan untuk dapat mengetahui letak kekurangan hasil pengembangan yang diperlukan untuk memberikan impact secara praktis yang disebabkan belum rigid-nya desain yang dikembangkan. Metode analisis menggunakan analisis SMART yakni Specific, Measurable, Attainable, Relevant, dan Timely.

\section{Lokasi penelitian}

Penelitian ini dilakukan di laboratorium Desain Komunikasi Visual Universitas Islam Nahdlatul Ulama Jepara, dengan lingkup pengambilan data motif ukir serta lokasi wisata pantai di wilayah Jepara.

\section{Kontribusi Penelitian}

Penelitian diharapkan memiliki manfaat secara praktis, yakni desain motif ukir baru yang terukur dan dapat diwujudkan purwarupanya, serta kemungkinan di tindaklanjuti dalam bentuk pembangunan infrastruktur oleh dinas pariwisata dan pemerintah kabupaten Jepara.

\section{Tinjauan Pustaka}

Perlunya penelitian terdahulu dalam menentukan kevaliditasan penelitian terkait dengan posisi penelitian dan kebaruannya, maka berikut ini dipaparkan beberapa penelitian dengan substansi penelitian yang relevan dengan peneliti sebelumnya antara lain oleh Shanti, U. A., \& Ratyaningrum, F. (2016: 253-259). Penelitian yang berjudul Pengembangan Motif Batik di U.D. Batik Satrio Manah Kabupaten Tulungagung. Penelitian ini fokus dalam lingkup pengembangan motif atau hiasan dalam material kain yang dibatik. Fokus pada analisa penggabungan motif yang sudah ada kemudian dihasilkan motif baru dan tidak disertai adanya riset lebih lanjut. Hal ini mampu memberikan fakta kebaruan yang diharapkan hanya memiliki durasi pemakaian sementara.

Penelitian selanjutnya oleh Wahjuni, S., Handini, Y. D., \& Khristianto, W. (2017: 114) berjudul Pengembangan Motif dan Produk Batik Tuban dalam Rangka Membangun Desa Wisata Batik di Kabupaten Tuban. Penelitian ini memiliki tujuan dalam pengembangan motif dan produk batik, akan tetapi lebih condong di dalam pembahasannya yang dilihat dari sudut ekonomi dan pemasaran, sehingga pengembangan produk dalam bentuk motif tidak didalami lebih mendetail.

Penelitian ini juga memiliki karakteristik yang hampir sama, yakni dilihat dalam perspektif ekonomi, sehingga pembahasan mengenai pengembangan motif dan produk batik hanya sebatas produksi dan bukan dari sisi teknis pengembangan produknya. Rahim, R., \& Husni, T. (2014: 218) dengan judul Pengembangan Model Sentra Industri KreatifMotif Kerajinan Minang Melalui Adaptability IKM, Inovasi, Kewirausahaan dan Keunggulan Kompetitif. Penelitian ini fokus pada peningkatan kinerja bisnis dengan desain, corak yang disesuaikan pada permintaan pasar, peningkatan keterampilan usaha, tata kelola keuangan serta produksi. Hasil penelitian ini. memberikan telaah dalam dan masukan dari sisi kebijakan terhadap pemerintah lokal, solusi akan manajemen dan pengembangan sebagai upaya mendorong dalam melakukan inovasi produk. Upaya dari sisi pengembangan motif tidak didalami secara lebih detail, sehingga apa yang disajikan cenderung masih dalam perspektif manajemen.

Dewi, R. A. M., dalam R. R., \& Indriani, E. (2016) melakukan penelitian berjudul Geometri Fraktal untuk Re-desain Motif Batik Gajah Oling Banyuwangi. Penelitian ini lebih fokus menelaah pengembangan motif batik dengan merumuskan konsep matematis dalam menciptakan motif baru, sehingga konsep pengembangan motif lebih ditekankan pada pemanfaatan rumus matematis dalam menciptakan kreasi dan hasil motif atau hiasan yang bervariatif. 
Desertasi oleh Sari, S. M., Wardani, L. K., \& Sitinjak, R. H. I. (2015) berjudul 'Implementasi Motif Batik pada Desain Modern dan Peran Pendidikan Seni dan Desain,' membahas tentang penerapan motif batik pada desain yang dianggap modern dikaitkan dengan dunia pendidikan seni dan desain. Konteks permasalahan dan pembahasan tidak luput dari perspektif dan konsep modern dalam balutan desain motif. Titik beratnya menjadikan objek daur ulang pada material desain yang berbeda, sehingga substansi pengembangan motif menjadi kabur.

Kaitan motif dengan dunia desain belum terlihat baik dari pustaka lama maupun terbarukan, sehingga terkait dengan beberapa penelitian sebelumnya yang telah dipaparkan, lebih banyak meyinggung motif sebagai subjek yang diolah dari ilmu manajemen, ekonomi, dan disiplin ilmu matematika serta desain rupa, sehingga posisi penelitian ini memiliki subtansi yang lebih mendalam walaupun dengan material yang hampir sama yakni motif (pola hias) dengan fokus motif ukir yang dikonseptualkan melalui desain.

Kajian penelitian ini akan lebih mendalami tentang bagaimana pengembangan desain melalui motif ukir sebagai penguat ikonik kota Jepara.

\section{Hasil Dan Pembahasan \\ Wisata Pantai Jepara}

Awal penelitian dilakukan tahap observasi meliputi sebaran wisata pantai dan jumlah pengunjung wisata pantai, sebagai data awal dalam menentukan seberapa banyak wisata pantai Jepara yang memiliki pengunjung terbanyak dengan tata kelola yang baik. Berikut paparan data peneliti yang disajikan dalam dua sub bab sebaran wisata pantai dan pengunjung wisata pantai.

\section{Sebaran Wisata Pantai Jepara}

Wisata pantai Jepara tersebar di titiktitik utara dan barat pulau Jawa berbatasan langsung ke laut Jawa. Jarak terdekat pusat pemerintahan kabupaten dengan dengan wisata pantai pantai adalah $4.5 \mathrm{~km}$, sedangkan jarak terjauh adalah $43.3 \mathrm{~km}$. Wisata dengan jarak terdekat adalah pantai Kartini Jepara, Teluk Awur $7.8 \mathrm{~km}$, Tirto Samudro 6,2 km (BPS, 2017). Untuk jarak tempuh yang di atas 7.8 km, seperti Pantai Pailus, Empu Rancak, Ombak Mati, Blebak, Bringin, Pungkruk, Goa Manik Pecatu. Sebanyak 11 objek wisata pantai yang beroperasi dan dikelola oleh pemerintah kabupaten maupun pemerintah desa setempat (“wisata," 2018).

Letak geografis Jepara yang berbukit dan berbatasan langsung dengan laut Jawa memang menjadi keuntungan tersendiri dari sisi potensi alam (BPS, 2017). Menilik potensi alam yang ada di sebaran, maka tak pelak membuat pemerintah kabupaten mengembangkan wisata alam dalam kontek wisata pantai. Permasalahan yang timbul lebih banyak dari segi pengelolaan dan infrastruktur yang belum baik, sehingga sampai tahun 2018 inipun pemerintah masih memfokuskan rencana stategis tentang pengelolaan wisata pantai di wilayah kabupaten Jepara (Disbudpar, 2012).

\section{Data Pengunjung Wisata}

Penelitian ini membutuhkan data kunjungan wisata pantai dalam kurun waktu 23 tahun dalam memberikan hipotesa dasar atas data yang komprehensif terkait dengan jumlah konsumen yang menjadi sasaran dalam menanamkan ikonik ukir di dalam benak konsumen terhadap suatu produk wisata yang diharapkan dari hasil uji desain ikonik wisata pantai terhadap suatu destinasi wisata. Berdasarkan data yang dihimpun dari laman resmi Tourism Information Center Jepara, data 
Matrik 1. Pengunjung Wisata Pantai Jepara 2016 (Sumber: Tic.Jepara.go.id, 2018)

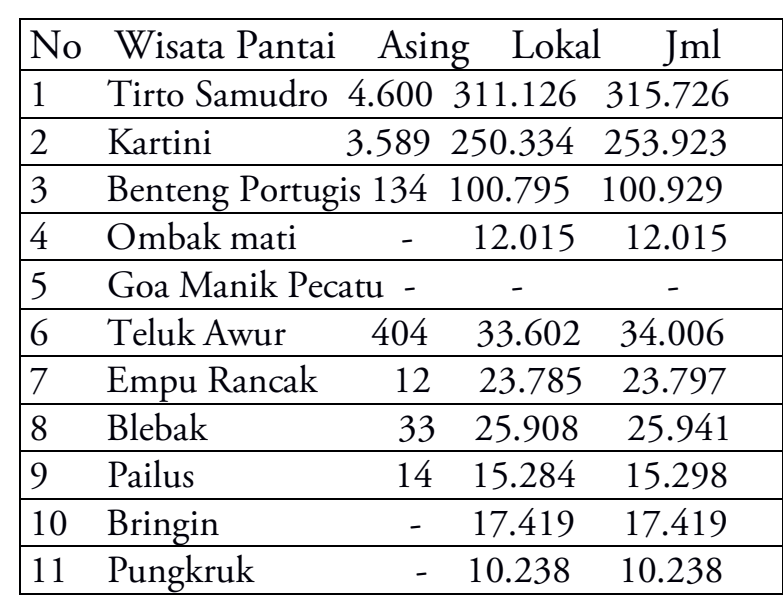

Matrik 2. Pengunjung Wisata Tertinggi per-tahun 2015-2017(Sumber: Tic.Jepara.go.id diolah oleh Peneliti, 2018)

\begin{tabular}{|llccc|}
\hline No & Wisata Pantai & Asing & Lokal & Jumlah \\
\hline 1 & Tirto Samudro & $4.459,3$ & $226.893,6$ & $298.019,6$ \\
\hline 2 & Kartini & $3.604,3$ & $223.826,3$ & $227.430,6$ \\
\hline 3 & Benteng Portugis & 148,6 & $99.962,6$ & $103.444,6$ \\
\hline
\end{tabular}

pengunjung dari Januari tahun 2017 sampai Desember 2017 untuk wisata pantai Jepara, sebanyak 195.418 terdapat di Pantai Kartini Jepara, kemudian 272.431 terdapat pengunjung di Pantai Tirto Samudro, 87.105 wisatawan terdapat di Pantai benteng Portugis. Pantai Teluk Awur sepanjang tahun terdapat sebanyak 62.742 wisatawan, Pantai Ombak Mati 85.445 pengunjung, pantai Goa Manik Pecatu 76.980, Pantai Teluk Awur 62.742, Pantai Empu Rancak, 35.629, Pantai Blebak 28.369, Pantai Pailus 18.763, Pantai Bringin 12.066, dan terahir Pantai Pungkruk 8.938 ("wisata," 2018). Pantai lain di wisata Jepara yang masuk dalam destinasi wilayah Pulau yakni Pulau Karimun Jawa dan Pulau Panjang, sehingga peneliti tidak dimasukkan sebagai data. Berikut sajian data dalam bentuk matrik yang disajikan oleh peneliti. Komparasi data pengunjung tahun 2017 mengalami penurunan pengunjung dari tahun 2016 berdasarkan angka statistik. Namun hal ini menurut Biro Humas
TIC tidak semua wisata pantai mengalami penurunan pengunjung, justru di beberapa destinasi wisata pantai seperti Pantai Blebak mengalami kenaikan pengunjung. Berikut data statistik pada tahun 2016 sebagai berikut.

Berdasarkan paparan data statistik di atas, maka dapat ditarik kesimpulan bahwa pengunjung wisata pantai di wilayah Kabupaten Jepara tertinggi terdapat pada lokasi Pantai Tirto Samudro dengan potensi kunjungan wisata manca dan lokal yang relatif di atas dua ribu pengunjung setiap tahun. Data tahun 2015 Tirto Samudro sebanyak 3.664 asing dan 302.238 lokal dengan jumlah pengunjung total 305.902 (Tic.Jepara.go.id: 8 Maret 2018). Hasil olah data dalam 3 tahun terahir didapatkan rata-rata pengunjung wisata asing sebanyak wisata lokal sebanyak 226.893,6 serta jumlah total rata-rata kunjungan Wisata Pantai Tirto Samudro 298.019,6. Berdasarkan hasil olah matrik 2 sebaran terbanyak kunjungan wisata, terdapat pada tiga lokasi wisata sehingga dalam merumuskan konsep identitas terkait dengan publikasi, maka potensi tiga lokasi wisata pantai berdasarkan matrik 2 adalah yang mampu memberikan dampak terhadap konsumen atau pengunjung terkait pengembangan desain melalui motif ukir untuk publikasi wisata pantai.

\section{Ukir}

Ukir di hampir semua daerah memiliki pola ukir tak terkeculi Jepara yang memang sudah terkenal akan motif ukirnya, dari Aceh sampai Papua terdapat berbagai macam ragam hias dalam bentuk motif. Ukir merupakan salah satu teknik yang dipakai dalam menerapkan motif hias ke dalam meterial yang bersifat keras maupun lunak, sedangkan untuk material yang lunak seperti tanah liat menggunakan teknik cetak tekan atau modelling untuk mengukirnya.

Studi literatur menemukan tahun 1985 terdapat proyek inventarisasi dan dokumentasi sejarah nasional yang dilakukan oleh Agus Dono Karmadi dan M, Sunjata 
Kardarmadja dalam dokumen yang dimiliki oleh Dinas Pendidikan dan Kebudayaan Nasional berjudul Sejarah Perkembangan Seni Ukir di Jepara. Motif ukir Jepara yang menarik adalah selalu terdapat ciri khas unik yakni:

(1) ukiran tersebut selalu terdapat lemahan atau dasar dari sebuah ukiran baik yang masih ditinggalkan maupun yang dihilangkan untuk lemahan yang dihilangkan, dikenal dengan istilah krawangan atau krawingan (lubang);

(2) terdapat umpak dan saling silang atau tumpang tindih (tingkatan tinggi rendah) bagian per bagian ukiran;

(3) pola motif ukiran meyesuaikan ruang media baik menggunakan pola geometris atau simetris; dan

(4) mengusung habitat sekitar lingkungan ukiran berkembang baik manusia, hewan, maupun tumbuhan. Keempat ciri ukiran yang peneliti deskripsikan di atas merupakan gambaran umum yang peneliti temukan di lapangan selama penelitian, sehingga besar kemungkinan ukir memilki tingkat kerumitan dan pengembangan yang bersifat lokal konten atau kearifan lokal dan berikut analisis berdasarkan gambar di bawah ini.

\section{Pemanfaatan Ikonik Ukir dan Publikasi Visual}

Hal yang mampu membuat wisatawan mencari hal baru atau terbarukan dan hal ini menjadi menarik manakala publikasi yang tepat dapat memberikan stimulan yang mampu membuat rekaman spesifik dalam benak konsumen Penataan ikonik yang baik dengan visual motif ukir yang tepat serta mampu dijadikan penunjang ikonik di lokasi pariwisata pantai sebagai daya tarik wisata merupakan satu kesatuan yang terintegrasi penuh dengan model tata ruang wisata, pengembangan, dan hasil riset sebelumnya merupakan tolakan peneliti dalam merumuskan sebuah konsep desain komunikasi visual yang baik dengan berdasarkan data tata kelola wisata. Berdasarkan hasil riset yang peneliti peroleh dari salah satu situs travelling Agoda Indonesia yang peneliti kutip dari Gede Gunawan, Country Director Agoda International Indonesia. Dikutip dari keterangan pers tertulis, Senin 1 Mei 2017 setidaknya terdapat sebanyak $80 \%$ menetapkan pilihan nuansa keindahan alam menjadi pilihan utama. Rasa penasaran menjadi, dalam hal ini adalah pengunjung wisata untuk menyimpan lebih lama dalam fikirannya.

Ikonik ukir adalah penentuan brand, menggunakan endorse wisata pantai sebagai wadahnya, sedangkan untuk menciptakan nuansa spesifik diperlukan citra yang berbeda, nyeleneh, atraktif, yang tujuan akhirnya mampu direkam dalam benak konsumen dalam waktu yang cukup lama. Hal inilah yang menjadi tujuan utama diperlukannya terobosan baru dalam membranding sebuah ikon wisata.

Terobosan-terobosan dalam dunia desain komunikasi visual telah banyak melahirkan hal yang spektakuler, salah satunya adalah teknologi dengan mengusung konsep ukir dengan lokal konten dipadukan dengan penataan lokasi yang baik, besar kemungkinan akan memberikan nuansa baru dan original, sehingga menarik banyak wisatawan hadir dan menikmatinya. Dengan konsep arsitektur yang dipakai serta bentuk dan kemasan yang berbeda dengan durasi dalam kurun waktu.

\section{Ide}

Berpatokan dan berpedoman pada data kunjungan wisata pantai serta hasil kajian ukir dan renstra Dinas Pariwisata dan Kebudayaan Kabupaten Jepara maka terdapat setidaknya poin-poin penting dalam mengarahkan peneliti dalam menggali ide tentang pengembangan desain melalui motif ukir untuk publikasi wisata pantai berikut peneliti rangkum dalam gambar berikut. relatif lama akan mampu memberikan kesan 


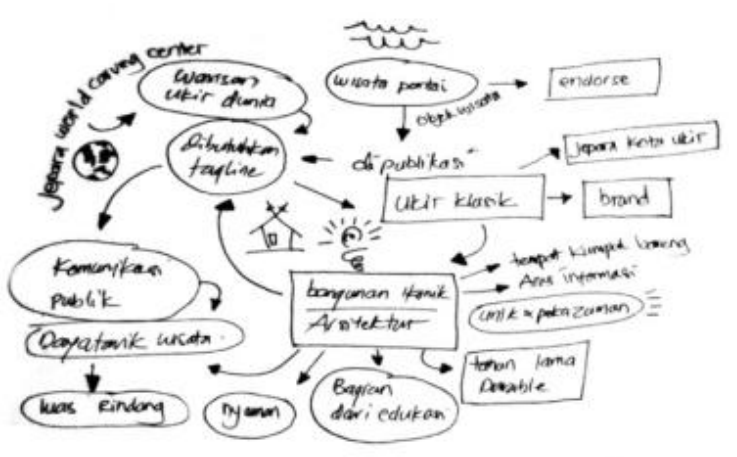

Gambar 1. Konsep Ide

(Sumber: Darmawanto dan Qomaruddin, 2018)

Mewujudkan ide dengan konsep unik dan peka zaman merupakan sesuatu yang tidaklah mudah, butuh pemikiran matang dan menggali ide yang dalam untuk mewujudkannya, setidaknya tantangan ke depan untuk desain ini adalah mampu bertahan dalam masa yang relatif lama dalam hitungan tahun, akan tetapi tetap mempertahankan konsep dengan mengusung dalam benak masyarakat atau pengunjung untuk menikmati sajian ikonik yang luar biasa.

\section{Pembuatan Motif Ukir}

Motif ukir dibuat berdasarkan data yang peneliti lakukan dengan melalui 2 proses. Yang pertama adalah melalui proses sketsa kasar atau rough layout dan seterusnya dilakukan proses pematangan desain dengan komputer atau final layout. Proses final layout memakan banyak waktu disebabkan adanya proses rough layout yang belum tentu dapat diadopsi keseluruhan butuh proses pematangan dan seleksi desain dari komponen motif. Diperlukan lokasi atau tempat yang menarik dengan megah serta ikon ukir dari sisi desain bangunan yang di area wisata pantai, sehingga citra komunikasi, desain, ikon mampu melebur menjadi satu.

\section{Konseptual Desain}

Pertanyaan yang saat ini tepat kiranya terkait dengan tagline "Jeparas World Carving Center" yang tepat untuk dijadikan ikonik ukir.
Berdasarkan beberapa hasil olah data sebelumnya bahwa setidaknya terdapat poin penting dalam pengembangan ikonik ukir melalui desain yang pertama adalah dalam mandatoris desain yang tepat yakni:

(1) terdapat motif ikonik ukir yang baru dan original dengan konten lokal;

(2) tidak bertentangan dengan renstra pengembangan wilayah wisata pantai dinas pariwisata dan kabupaten Jepara dan bebas dari unsur eksklusivitas;

(3) mampu terintergrasi dengan arsitektur lokal dan mengikuti zaman dalam waktu yang lama;

(4) bentuk desain harus menguatkan unsur ikonik ukir dan menjadi tempat wisata pantai; dan

(5) menjadi tempat yang mampu memberikan unsur komunikasi visual dari sisi publikasi. Mandatoris yang peneliti ungkapkan kiranya relevan dengan data dari kajian yang telah peneliti lakukan terhadap data yang diperoleh. Mensikapi mandataroris yang dirumuskan, maka kiranya tidak berlebihan apabila konsep yang tertuang mengusung konsep unik dan peka zaman, ukir yang menjadi ikoniknya, berikut peneliti rangkum dalam matrik.

Matrik 4. Implementasi Ide(Sumber: Darmawanto dan Qomaruddin, 2018)

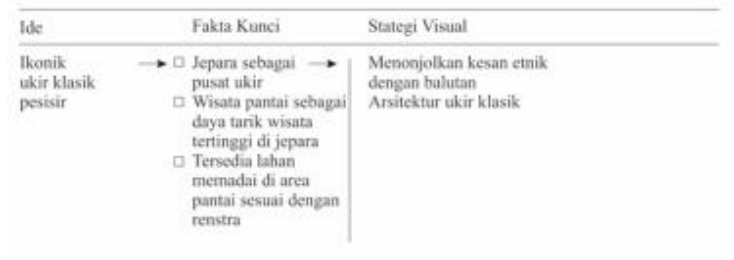


Matrik 3. Analisis ciri-ciri ukiran(Sumber: Darmawanto 2018)

\begin{tabular}{|c|c|c|c|}
\hline & VisualUkir & Ciri & Material \\
\hline 1 & & $\begin{array}{l}\text { 1. Lemahan/karawangan terdapat pada bagian yang } \\
\text { dibuat berlubang. } \\
\text { 2. Umpak terlihat pada bagian yang dibuat di } \\
\text { bagian bawah dan bagian atas yang tersusun } \\
\text { berjajar. } \\
\text { 3. Membentuk pola patran atau segi tiga. } \\
\text { 4. Kearifan lokal yang diusung terlihat pada motif } \\
\text { daun yang digubah merupakan motif daun } \\
\text { kluwih yang berada di sekitar lingkungan } \\
\text { pengrajin. }\end{array}$ & Tanah liat \\
\hline 2 & & $\begin{array}{l}\text { 1. Lemahan/karawangan terdapat pada sela-sela lung } \\
\text { daun dan batang pohon. } \\
\text { 2. Umpak terdapat pada bagian lingkaran dan motif } \\
\text { ukirang yang dibuat berjenjang tinggi rendahnya. } \\
\text { 3. Membentuk pola melingkar sesuai pola dengan } \\
\text { batas lingkaran yang dibentuk pada bagian luar. } \\
\text { 4. Kearifan lokal mengangkat pohon jambu air } \\
\text { yang banyak terdapat di sekitar Jepara. }\end{array}$ & Batu \\
\hline 3 & & $\begin{array}{l}\text { 1. Lemahan/karawangan dibuat dengan tidak rata } \\
\text { yang menyesuaikan kebutuhan kedalaman } \\
\text { ukiran. } \\
\text { 2. Umpak terlihat pada tumpang tindih ukiran. } \\
\text { 3. Membentuk pola pemandangan pedesaan yang } \\
\text { umum terdapat di kota Jepara waktu lampau. } \\
\text { 4. Kearifan lokal mengangkat suasana pedesaan } \\
\text { khas indonesia dengan aktifitasnya }\end{array}$ & Kayu \\
\hline
\end{tabular}

Seleksi motif berdasarkan data dan masukan dikonsultasikan kepada budayawan Suharto sekaligus pemerhati ukir Jepara Universitas Islam Nahdlatul Ulama Jepara (UNISNU), maka pilihan jatuh pada pembuatan motif baru dengan dasar bentuk wuwung rumah warga Jepara pada umumnya.

Komponen-komponen motif ukir dalam final layout ukir terdapat beberapa istilah. Berikut beberapa istilah yang peneliti berikan secara khusus dan beberapa istilah umum yang memang sering dipakai untuk motif sejenis.

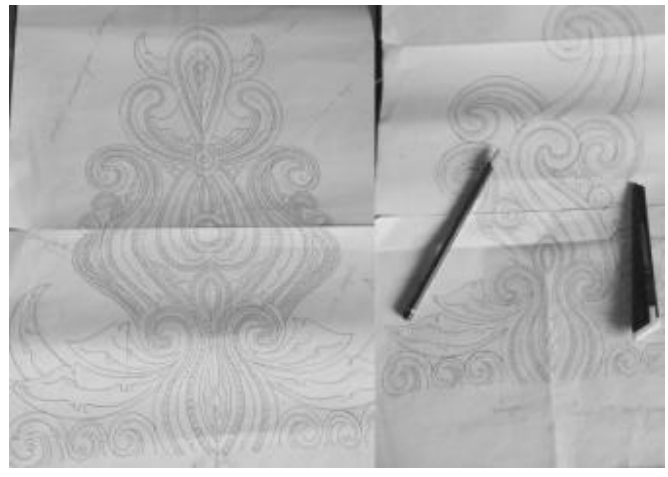

Gambar 2. Rough Layout motif ukir (Sumber: Darmawanto, 2018) 

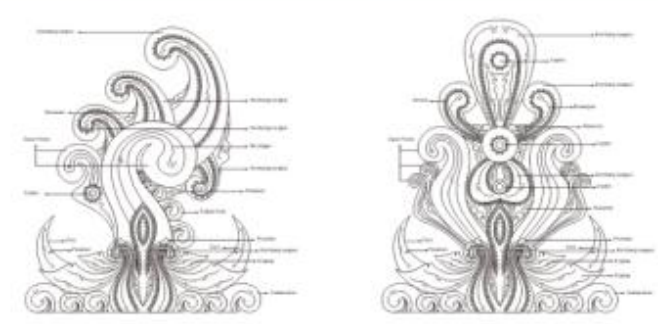

Gambar 3. Final Layout (Sumber: Darmawanto, 2018)

\section{Kembang tungkul}

Kembang tungkul merupakan pola gubahan dari bunga yang menyembul dari daun pokok. Ciri utama dari kembang tungkul adalah menyerupai kelopak bunga dengan kelopak berjumlah genap maupun bunga yang belum mekar (kuncup).

\section{Ceplok}

Ceplok adalah pola lingkaran yang terdapat pada tengah tengah kembang tungkul maupun daun pokok.

\section{Simbar}

Simbar adalah bentuk stilasi daun kecil yang menyembul di antara kembang tungkul, sedangkan dalam daun pokok tidak ada.

\section{Benangan}

Benangan merupakan bentuk garis berada di tengah-tengah setiap komponen motif yang dibuat sejalur dengan arah motif untuk setiap komponen motif.

\section{Kleweran}

Kleweran merupakan kelopak bunga kecil yang muncul di sela-sela bagian kelopak besar kembang tungkul.

\section{Daun pokok}

Daun pokok merupakan pangkal dari daun atau pokok motif utama. Ciri utama dari daun pokok ini tidak terdapat simbar dan hanya ada benangan.

\section{Culo}

Culo merupakan pola menyerupai bentuk cula pada hewan badak, namun cula pada motif ukir klasik ini merupakan putik bunya yang muncul di sela-sela angkup.

\section{Pecahan}

Pecahan merupakan bagian motif yang dibuat untuk membelah komponen motif. Pecahan hanya terdapat di bagian komponen culo dan angkup, ciri utama menyerupai bentuk sobek atau sobekan.

\section{Angkup}

Angkup merupakan bagian bawah bunga tungkul tempat melindungi putik bunga.

\section{Trubus telon}

Trubus atau trubusan merupakan bentuk ukel daun yang belum terbentuk secara sempurna, muncul di bagian bawah motif dan punggung daun pokok, ciri utama dari trubusan telon merupakan jumlah trubusan yang berjumlah ganjil.

\section{Kelir lanang}

Kelir lanang merupakan bagian dari motif ukir klasik yang terdapat pada bagian atas berbetuk simetris kanan dan kiri. Kelir Lanang adalah sebagai simbol laki-laki dengan sifat pengayom, pekerja keras sesuai dengan namanya lanang yang berarti laki-laki.

\section{Kelir apit}

Kelir apit merupakan bagian motif ukir klasik yang terdapat pada bagian bawah berbentuk asimetris. Kelir apit dalah simbol dari perempuan dengan sifat pendamping, pelengkap, pemberi semangat, dan kasih sayang. 


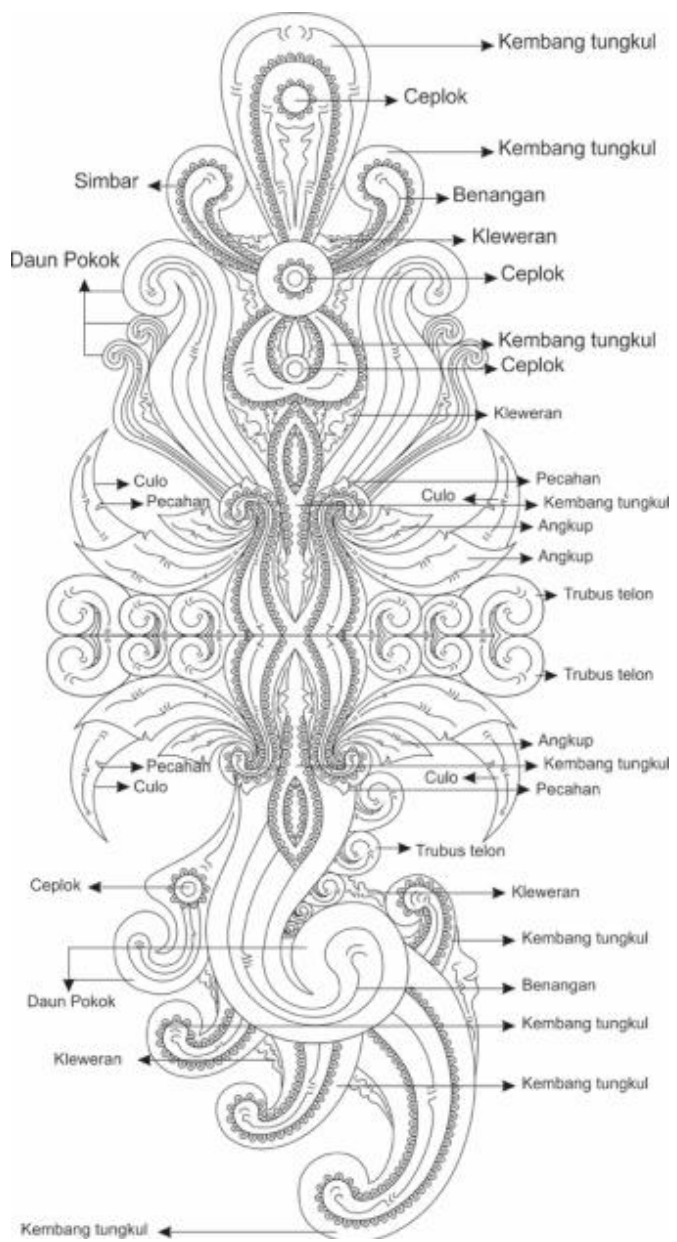

Gambar 4. Ukir klasik

(Sumber: Darmawanto, 2018)

\section{Validasi Desain}

Melakukan validasi desain adalah proses tolak ukur desain dapat dibuat dan diaplikasi dalam bentuk nyata. Tahap kalkulasi desain yang menjadi fokus peneliti adalah dalam hal ukir klasik yang telah diciptakan sebagai penunjang wisata pantai. Mampu setidaknya ukiran dibuat sesungguhnya menggunakan material kayu atau batu atau tanah liat. Berikut proses validasi desain dibuat nyata dalam material tanah liat. Berdasarkan ketiga material tersebut tanah liat adalah yang paling cepat dalam melakukan rekayasa teknik ukir. Banyak keunggulan yang dapat diperoleh, salah satunya adalah tidak membuang material kerja sehingga mampu menghemat material uji.
Teknik yang dipergunakan adalah teknik pahat menggunakan alat butsir serta modelling (clay carving). Dengan menggabungkan teknik ini, peneliti memiliki keuntungan lain, yakni mampu merestorasi gaya ukiran apabila terdapat kesalahan bentuk. Berikut hasil validasi desain peneliti sajikan dalam gambar.

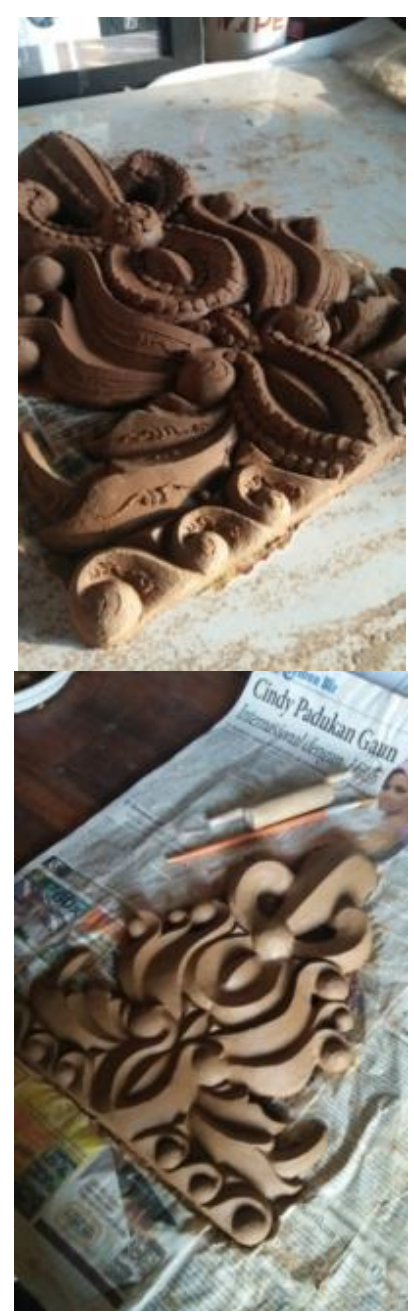

Gambar 5. Validasi desain ukir klasik (Sumber: Darmawanto, 2018)

Berdasarkan data hasil validasi menunjukkan desain telah mampu dibuat dengan baik menggunakan material tanah liat, sehingga apabila diproses menggunakan material lain akan menghasilkan karya yang sama meskipun dengan alat yang berbeda. 


\section{Analisis (SMART)}

Implementasi ikonik ukir dibuat dalam bentuk pintu gerbang sebagai desain landscaping masuk dan keluar wisata pantai. Gerbang merupakan area strategis dalam melakukan pengulangan informasi, kondisi pengunjung keluar dan masuk area wisata secara otomatis akan melalui pintu gerbang. Ikonik ukir yang disematkan di pintu gerbang akan memberikan pesan dalam benak pengunjung wisata pantai sebagai citra yang

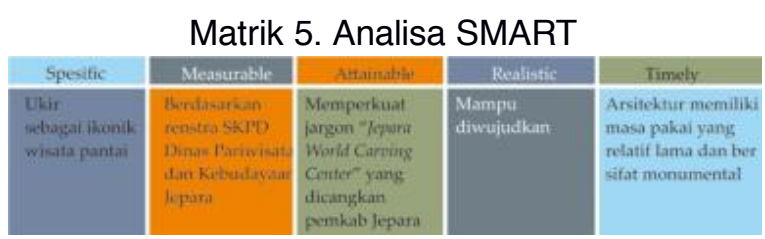

(Sumber: Darmawanto, 2018)

\section{Ikonik Ukir Wisata Pantai}

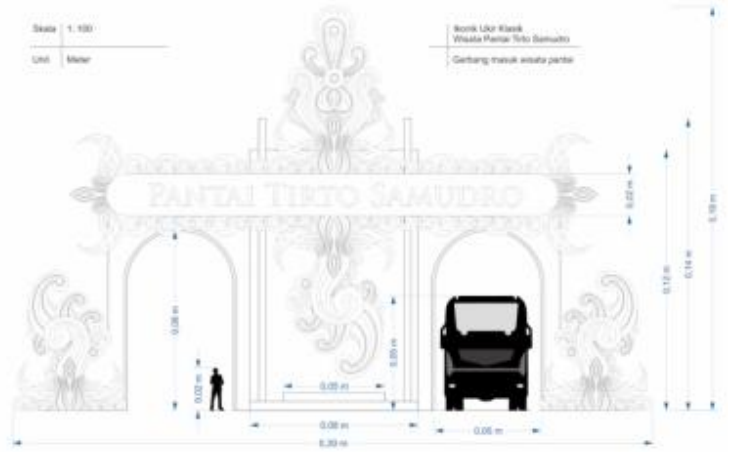

Gambar 6. Landscaping Ikonik Ukir Klasik Wisata Pantai

(Sumber: Darmawanto, Qomaruddin, 2018)

melekat serta pesan psikologis sebagai penguat pesan utama bahwa Jepara merupakan pusat ukir dunia. Selain sebagai penguat citra ukir wisata pantai dengan ikonik ukir juga akan menjadi simbol wisata unik yang memadukan lokal konten sebagai warisan budaya dengan balutan edukasi, tentunya dengan penambahan konten sign system, public information, dan beberapa area dengan mengusung ikonik ukir.

\section{Kesimpulan}

Berbagai hal yang telah dipaparkan mencakup wisata pantai Jepara dengan sebaran wisata pantai serta data pengunjung dengan komparasi jumlah pengunjung wisata guna sebaran informasi ikonik, kemudian data ragam ukir klasik dan pemanfaatan ikonik guna publikasi wisata pantai didapatkan 3 kesimpulan sebagai berikut.

1. Berdasarkan hasil validasi motif ukir klasik yang tercipta, mampu diwujudkan dengan baik menggunakan material tanah liat sebagai tahap uji implementasi. Hal ini membuktikan bahwa motif yang tercipta mampu mewakili sebagai ikonik yang ditargetkan. Namun dari segi publikasi ikonik ukir untuk wisata pantai Jepara sangat dipengaruhi oleh variabel demografi wilayah, sehingga membutuhkan survei lanjut berdasarkan kebutuhan lokal wisata, sehingga tidak semua wisata pantai Jepara dapat mengusung ikonik ukir yang peneliti hasilkan saat ini. Fakta bahwa jumlah pengunjung sebagai komunikan wisata serta area lokasi wisata yang memadai untuk diciptakannya sebuah ikonik ukir klasik juga tata kelola wisata oleh pihak tertentu menjadi faktor publikasinya.

2. Berdasarkan hasil analisis SMART kemungkinan motif ukir klasik di implementasikan, maka sangat besar kemungkinan motif ukir klasik menjadi ikon baru yang regeneratif, artinya tidak hanya sebatas ikonik wisata pantai namun motif ini juga mampu dimplementasikan dalam berbagai material tidak terkecuali untuk industri furniture. Hal ini membuktikan bahwa ikonik ukir klasik masih mampu menjadi daya tarik yang memiliki potensi publikasi dengan lokal konten yang membawa nama Jepara dalam wadah yang berbeda sebagai warisan budaya, serta mendukung ciri khusus sebuah daerah.

\section{Ucapan Terimakasih}

1. Ucapan terimakasih yang pertama kami sampaikan kepada DRPM Dikti yang telah 
memberikan kesempatan dan mendanai penelitian ini tahun anggaran 2017/2018 Nomor: 34/K6/KM/SP2H/PENELITIAN/2018, sehingga dapat terlaksana dan memberikan kontribusi positif dalam skema penelitian dosen pemula (PDP).

2. Ucapan terima kasih yang kedua kami sampaikan kepada LPPM Universitas Islam Nahdlatul Ulama Jepara beserta jajarannya, serta Fakultas Sains dan Teknologi terutama Prodi Desain Komunikasi Visual, yang telah memfasilitasi semua kegiatan penelitian sampai berakhirnya penelitian PDP ini dengan baik.

3. Ucapan terima kasih yang ketiga kami sampaikan kepada pihak pemerintah kabupaten dalam hal ini adalah lembaga Pemerintah Kabupaten Jepara, Dinas Pariwisata dan Kebudayaan Jepara, pihak Pemerintah Desa Mulyoharjo atas kontribusi serta izin penelitian yang diberikan.

4. Ucapan terima kasih yang keempat disampaikan kepada seluruh pihak yang tidak dapat kami tuliskan satu-persatu yang telah turut serta membantu segala upaya penelitian ini sehingga mampu terlaksana dengan baik.

\section{Kepustakaan}

BPS. (2017). Kecamatan Jepara Dalam Angka 2017. Jepara. Jepara: BPS Jepara.

Departemen Pendidikan Nasional. (2008). Kamus Besar Bahasa Indonesia. Jakarta: PT. Gramedia Pustaka.

Dewi, R. A. M., dari, R. R., \& Indriani, E. (2016). Geometri Fraktal untuk Re-desain Motif Batik Gajah Oling Banyuwangi. Jurnal Pendidikan Matematika Tadulako,. Jurnal Pendidikan Matematika Tadulako, 5(2).

Disbudpar. (2012). Rencana Strategis Satuan Kerja Perangkat Daerah (renstra skpd) Dinas Pariwisata dan Kebudayaan Kabupaten Jepara Tahun 2012 - 2017. Jepara: Dinas Pariwisata dan Kebudayaan Kabupaten Jepara.
Eko Darmawanto, Muchammad Qomarrudin Desain Motif Ukir..

Jdih.jeparakab.go.id. (2014). peraturan bupati 2014. Retrieved from jdih.jeparakab.go.id

Rahim, R., \& Husni, T. (2014). Pengembangan Model Sentra Industri Kreatif Motif Kerajinan Minang Melalui Adaptability IKM, Inovasi, Kewirausahaan dan Keunggulan Kompetitif. Jurnal Kajian Manajemen Bisnis,3(2).

Sari, S. M., Wardani, L. K., \& Sitinjak, R. H. I. (2015). Implementasi Motif Batik pada Desain Modern dan Peran Pendidikan Seni dan Desain. Surabaya: Petra Christian University.

Shanti, U. A., \& Ratyaningrum, F. (2016). Pengembangan Motif Batik di UD. Batik Satrio Manah Kabupaten Tulungagung. Jurnal Mahasiswa Teknologi Pendidikan., $4(2)$.

Wahjuni, S., Handini, Y. D., \& Khristianto, W. (2017). Pengembangan Motif dan Produk Batik Tuban dalam Rangka Membangun Desa Wisata Batik di Kabupaten Tuban. Tuban.

http://wisata. (2018). Retrieved from http://tic.jepara.go.id.wisata/di unduh pada tanggal 9/02/2018 